\title{
Effect of prostaglandin $\mathrm{D}_{2}$ on histamine-induced weals in human skin
}

\author{
Vanessa F. Barnes \& Dennis J. Heavey ${ }^{1}$ \\ Department of Clinical Pharmacology, Royal Postgraduate Medical School, London W12 0HS
}

1 The effect of prostaglandin $\mathrm{D}_{2}\left(\mathrm{PGD}_{2}\right)$ on weal response to intradermal injection of histamine was examined in normal volunteers.

2 Co-injection of variable amounts of $\mathrm{PGD}_{2}$ with a fixed dose of histamine ( $\left.2.5 \mathrm{nmol}\right)$ was made so that the molar ratio of histamine: $\mathrm{PGD}_{2}$ covered the range 15 to 1215 . There was no significant effect of $\mathrm{PGD}_{2}$ on weal area.

$3 \mathrm{PGD}_{2}$, present at a 50 times lower concentration than histamine, had no effect on either the doseresponse curves for the histamine-induced weal area or the forearm weal volume response to $2.5 \mathrm{nmol}$ histamine.

4 It is concluded that $\mathrm{PGD}_{2}$, when present at the relative amounts found in vitro and in vivo, has no effect on the weal response to histamine in man.

\section{Introduction}

Prostaglandin $\mathrm{D}_{2}\left(\mathrm{PGD}_{2}\right)$ is the major prostaglandin produced when human mast cells degranulate (Lewis et al., 1982) and in man is able to cause bronchoconstriction (Hardy et al., 1984), vasodilatation (Heavey et al., 1984), and weal formation (Soter et al., 1983). It has therefore been proposed as an important inflammatory mediator.

Immunological challenge of human mast cells or lung parenchyma in vitro leads to the release of between 30 and 600 times more histamine than $\mathrm{PGD}_{2}$ (Schulman et al., 1981; Lewis et al., 1982). In vivo, concentrations of histamine in blood draining urticated skin are 271 to 1242 times higher than those of $\mathrm{PGD}_{2}$ (Heavey et al., 1985). $\mathrm{PGD}_{2}$ and histamine are approximately equipotent in the production of weals in human skin (Soter et al., 1983). It is therefore unlikely that $\mathrm{PGD}_{2}$ contributes significantly through direct vascular effects to the weal formation seen following immunological mast cell degranulation. However, $\mathrm{PGD}_{2}$ is able to potentiate vascular permeability induced by histamine in rat skin (Flower $e t$ al., 1976); therefore, we have investigated its ability to potentiate histamine-induced weals in man.

\footnotetext{
${ }^{1}$ Present address and correspondence: Brigham and Women's Hospital, The Seeley G. Mudd Building, 6th Floor, 250 Longwood Avenue, Boston, MA 02115, U.S.A.
}

\section{Methods}

\section{Subjects}

A total of 18 subjects ( 2 female), aged $22-40$ years was examined. All gave written, informed consent and the study was approved by the Ethics Committee of Hammersmith Hospital and Royal Postgraduate Medical School. No drugs, with the exception of the oral contraceptive, were taken for at least 3 days before any study.

\section{Intradermal injections}

All intradermal injections were made in a volume of either 50 or $20 \mu l$ as stated, with a 27 gauge needle. Each weal was formed by a single injection, appropriate stock concentrations of histamine and $\mathrm{PGD}_{2}$ mixtures being made beforehand. For measurement of weal volume, injections were made on the volar aspect of the forearm, all other injections being made in the back.

\section{Weal area and volume}

Weals were measured $10 \mathrm{~min}$ after injection. A ballpoint pen was used to draw around any raised or indurated area and the image transferred to plain 
paper with clear adhesive tape. The area was subsequently measured with a digitising pad and calculated according to the trapezoid rule. To estimate weal thickness, the skin was drawn up in a fold between the jaws of a micrometer screw gauge. The gauge was closed with a ratchet operating at fixed tension. Skin fold thickness was also measured before injection and weal thickness taken as half the difference between the $10 \mathrm{~min}$ and pre-injection values. Volume was calculated as area $\times$ thickness. Measurements were made by an observer who was unaware of the nature of each injection. During measurements of skin thickness the micrometer gauge was not visible to the observer.

\section{Protocols}

(a) Variable ratio $P G D_{2}$ : histamine $\mathrm{A}$ total of $8 \times 50 \mu$ injections was given to each of 9 subjects. Injections were given in randomised order, 4 each side of the midline. A fixed dose of $2.5 \mathrm{nmol}$ histamine was combined with variable amounts of $\mathrm{PGD}_{2}$ so that the molar ratio of histamine: $\mathrm{PGD}_{2}$ covered the range 15 to 1215 (167 to $2.06 \mathrm{pmol}^{\mathrm{PGD}_{2}}$ ). Control injections of saline, histamine alone $(2.5 \mathrm{nmol})$, and $\mathrm{PGD}_{2}$ alone $(167 \mathrm{pmol})$ were made.

(b) Dose-response to histamine A total of $10 \times 20 \mu 1$ injections were given to each of 8 subjects. Histamine was injected in doses of $0.33,1.0,3.0$ and $9.0 \mathrm{nmol}$ with

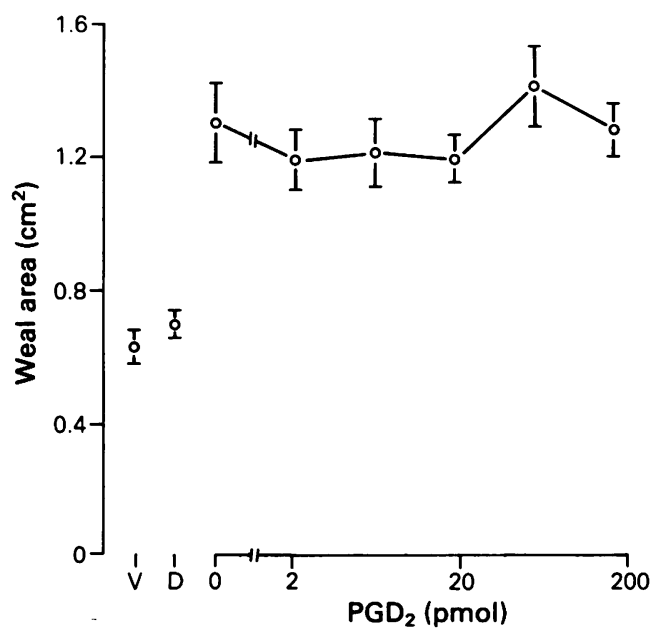

Figure 1 Effect on weal area of variable amounts of prostaglandin $\mathrm{D}_{2}\left(\mathrm{PGD}_{2}\right)$ coinjected with $2.5 \mathrm{nmol}$ histamine. $V=$ vehicle (saline), $D=P \mathrm{PD}_{2}(167 \mathrm{pmol})$. Each point represents the mean and vertical lines indicate s.e.mean; $n=9$. There is neither an overall effect of $P G D_{2}$ on the histamine-induced weal area (analysis of variance), nor a significant effect at any single ratio of $\mathrm{PGD}_{2}$ to histamine (paired $t$ test).

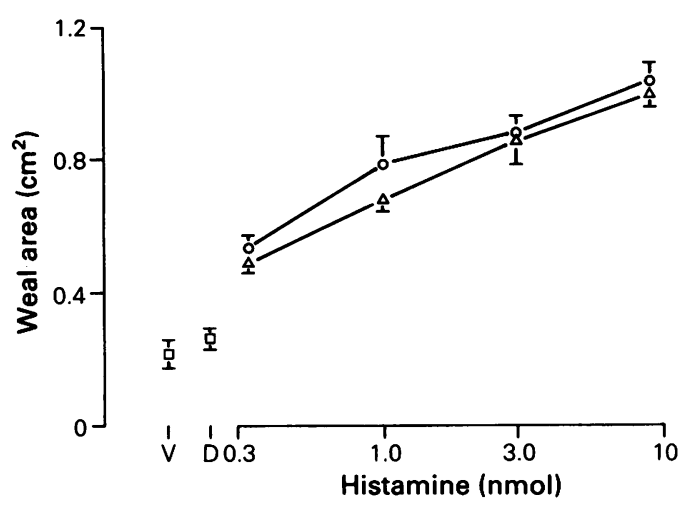

Figure 2 Dose-response curves for the weal area induced by histamine alone $(\Delta)$ and histamine plus a 50 fold lower concentration of prostaglandin $\mathrm{D}_{2}\left(\mathrm{PGD}_{2} ; \mathrm{O}\right)$. $\mathrm{V}=$ vehicle (saline), $\mathrm{D}=\mathrm{PGD}_{2}(180 \mathrm{pmol})$. Injections were made in a volume of $20 \mu$ lo reduce the control weal areas. Each point represents the mean and vertical lines indicate s.e.mean; $n=8$.

or without $\mathrm{PGD}_{2}$ present at a 50 times lower dose (6.6, $20,60,180 \mathrm{pmol})$. Saline and $\mathrm{PGD}_{2}$ alone $(180 \mathrm{pmol})$ were included as controls. Order of injection was randomised, but corresponding injections of histamine alone or histamine with $\mathrm{PGD}_{2}$ were made at the same level either side of the midline.

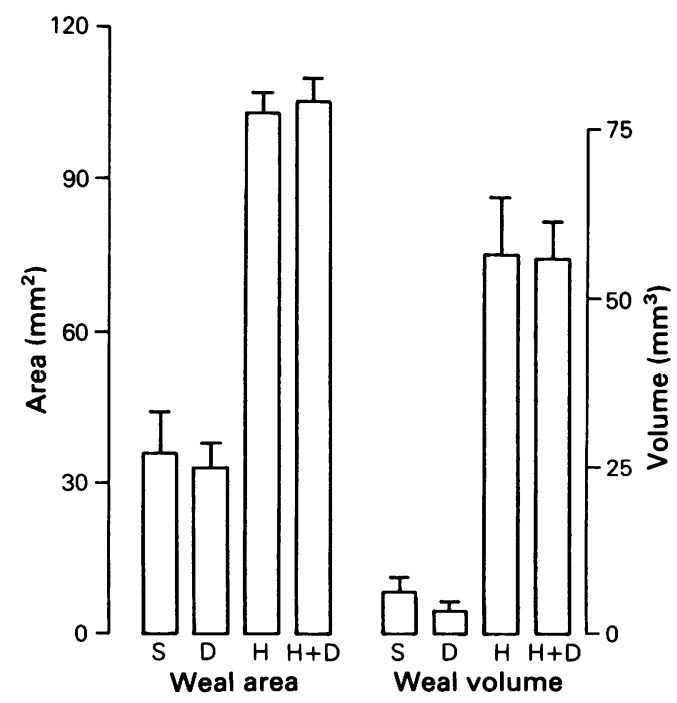

Figure 3 Forearm weal areas and volumes produced by $2.5 \mathrm{nmol}$ histamine alone $(\mathrm{H})$ and in the presence of 50 pmol prostaglandin $\mathrm{D}_{2}\left(\mathrm{PGD}_{2}\right)(\mathrm{H}+\mathrm{D})$. $\mathrm{V}=$ vehicle (saline), $\mathrm{D}=\mathrm{PGD}_{2}$ (50 pmol). Columns represent mean values with s.e.mean bars; $n=12$. 
(c) Weal volume Four $50 \mu$ injections were made in each of 12 subjects. Histamine was injected either alone $(2.5 \mathrm{nmol})$ or in combination with $\mathrm{PGD}_{2}$ at a concentration $(50 \mathrm{pmol}) 50$ times less than that of histamine. Saline and $\mathrm{PGD}_{2}$ alone $(50 \mathrm{pmol})$ were included as controls. One control and one histaminecontaining injection were made in each forearm, corresponding injections being made at the same distance from the elbow.

\section{Statistics}

Weal areas and volumes were compared by the paired, two tailed $t$ test. Analysis of variance was used to determine whether there was an overall effect of PGD $_{2}$ in the variable dose study. Significance was taken as $P<0.05$.

\section{Drugs}

Histamine was injected as the acid phosphate (British Pharmacopoeia). PGD $_{2}$ was supplied as a sterile solid (Glaxo Group Research, Herts) and stored at $-80^{\circ} \mathrm{C}$ as a $60 \mu \mathrm{M}$ solution in sterile isotonic saline. Concentration of $\mathrm{PGD}_{2}$ was checked by gas chromatography/ mass spectrometry (Waddell et al., 1984). All dilutions of histamine and $\mathrm{PGD}_{2}$ were freshly made in sterile isotonic saline.

\section{Results}

Injection into the skin of the back of $2.5 \mathrm{nmol}$ histamine in a $50 \mu$ l volume produced a weal of mean area $1.30 \pm 0.12 \mathrm{~cm}^{2}$ ( \pm s.e.mean $)$. The weal area was not affected by co-injection of $\mathrm{PGD}_{2}$ in amounts ranging from 2.06 to $167 \mathrm{pmol}$ representing molar ratios histamine: PGD $_{2}$ of between 1215 and 15 to 1 (Figure 1).

Weal area produced by histamine injected in a $20 \mu \mathrm{l}$ volume over the dose range 0.33 to $9.0 \mathrm{nmol}$ was not affected when $\mathrm{PGD}_{2}$ was present at a 50 times lower concentration (Figure 2).

In forearm skin neither weal area nor volume produced by $2.5 \mathrm{nmol}$ histamine was affected by the presence of $\mathrm{PGD}_{2}$ at a concentration 50 times lower than that of histamine (Figure 3).

\section{References}

BASRAN, G.S., PAUL, W., MORLEY, J. \& TURNER-WARWICK, M. (1982). Evidence in man of synergistic interaction between putative mediators of acute inflammation and asthma. Lancet, i, 935-937.

CHAPNICK, B.M., FEIGEN, L.P., HYMAN, A.L. \& KAD-

\section{Discussion}

In our first study we examined the effect of $\mathrm{PGD}_{2}$ on a single dose of histamine $(2.5 \mathrm{nmol})$ which lies on the linear part of the histamine weal dose-response curve. Variable amounts of $\mathrm{PGD}_{2}$ were used to cover the range of ratios found in vivo and in vitro. No significant effect of $\mathrm{PGD}_{2}$ was found either overall or at any particular ratio. There was a small increase in weal size at a histamine: $P G D_{2}$ ratio of $45: 1$ and so the effect of a similar ratio on the histamine dose-response curve was studied. There was no effect of $\mathrm{PGD}_{2}$ on histamine-induced weal formation at any part of the curve. A well recognized interaction of inflammatory mediators in skin is the potentiation of bradykinininduced weals by the vasodilator PGE $_{2}$. This is due almost entirely to an increase in weal thickness rather than area (Basran et al., 1982). We therefore examined the effect of $\mathrm{PGD}_{2}$ on histamine-induced weal area and volume in the forearm but again found no potentiation.

It is concluded therefore that, when present in the relative amount seen following mast cell degranulation, $\mathrm{PGD}_{2}$ is unable to potentiate histamine-induced weal formation in human skin. The discrepancy between this result and that found in rats may be because a different method, extravasation of radiolabelled albumin, was used to assess permeability, or because species differences exist in the permeability response to $\mathrm{PGD}_{2}$. Such differences certainly exist in the vasoconstrictor or vasodilator responses to $\mathrm{PGD}_{2}$ (Wasserman et al., 1977; Chapnick et al., 1978; Fletcher \& Ramwell, 1980; Wechsung \& Houvenaghel, 1981). There has been a study showing that $\mathrm{PGD}_{2}$ can potentiate histamine-induced bronchoconstriction in man (Fuller et al., 1984). If extrapolation can be made from skin to mucosal permeability, our results suggest that any potentiation of histamine-induced bronchoconstriction by $\mathrm{PGD}_{2}$ is more likely to occur at bronchial smooth muscle than through enhanced mucosal oedema.

We would like to thank Glaxo Group Research, Ware, Herts, for the kind gift of $P G D_{2}$. This work was supported in part by an MRC programme grant. D.J.H. is an MRC Training Fellow.
OWITZ, P.J. (1978). Differential effects of prostaglandins in the mesenteric vascular bed. Am. J. Physiol., 235, H326-H332.

FLETCHER, J.R. \& RAMWELL, P.W. (1980). Haemodynamic evaluation of prostaglandin $D_{2}$ in the conscious baboon. 
In Advances in Prostaglandin and Thromboxane Research, Vol. 7. ed. Samuelsson, B., Ramwell, P.W. \& Paoletti, R. pp. 723-725, New York: Raven Press.

FLOWER, R.J., HARVEY, E.A. \& KINGSTON, W.P. (1976). Inflammatory effects of prostaglandin $D_{2}$ in rat and human skin. Br. J. Pharmac., 56, 229-233.

FULLER, R.W., DIXON, C.M., DOLLERY, C.T. \& BARNES, P.J. (1984). Inhaled prostaglandin $D_{2}$ potentiates histamine induced bronchoconstriction. Thorax, 39, 699-700 (Abstr.)

HARDY, C.C., ROBINSON, C., TATTERSFIELD, A.E. \& HOLGATE, S.T. (1984). The bronchoconstrictor effect of inhaled prostaglandin $D_{2}$ in normal and asthmatic men. N. Engl. J. Med., 311, 209-213.

HEAVEY, D.J., LUMLEY, P., BARROW, S.E. MURPHY, M.B., HUMPHREY, P.P. \& DOLLERY, C.T. (1984). Effects of intravenous infusions of prostaglandin $\mathrm{D}_{2}$ in man. Prostaglandins, 28, 755-768.

HEAVEY, D.J., KOBZA-BLACK, A., BARROW, S.E., CHAPPELL, C.G., GREAVES, M.W. \& DOLLERY, C.T. (1985). Prostaglandin $\mathrm{D}_{2}$ and histamine release in cold urticaria. Br. J. Clin. Pharmac., 20, 270P.

LEWIS, R.A., SOTER, N.A., DIAMOND, P.T., AUSTEN, K.F., OATES, J.A. \& ROBERTS II, L.J. (1982). Prostaglandin D generation after activation of rat and human mast cells with anti-IgE. J. Immunol., 129, 1627-1631.
SCHULMAN, E.S., NEWBALL, H.H., DEMERS, L.M., FITZPATRICK, F.A. \& ADKINSON Jr, N.F. (1981). Anaphylactic release of thromboxane $A_{2}$, prostaglandin $D_{2}$ and prostacyclin from human lung parenchyma. Am. Rev. resp. Dis., 124, 402-406.

SOTER, N.A., LEWIS, R.A., COREY, E.J. \& AUSTEN, K.F. (1983). Local effects of synthetic leukotrienes ( $\mathrm{LTC}_{4}$, $\mathrm{LTD}_{4}, \mathrm{LTE}_{4}$ and $\mathrm{LTB}_{4}$ ) in human skin. $J$. invest. Dermatol., 80, 115-119.

WADDELL, K.A., BARROW, S.E., ROBINSON, C., ORCHARD, M.A., DOLLERY, C.T. \& BLAIR, I.A. (1984). Quantitative analysis of prostanoids in biological fluids by combined capillary column gas chromatography negative ion chemical ionisation mass spectrometry. Biomed. Mass. Spectrom., 11, 68-74.

WASSERMAN, MA. DUCHARME, D.W., GRIFFIN, R.L., DE GRAAF, G.L. \& ROBINSON, F.G. (1977). Bronchopulmonary and cardiovascular effects of prostaglandin $\mathrm{D}_{2}$ in the dog. Prostaglandins, 13, 255-269.

WECHSUNG, E. \& HOUVENAGHEL, A. (1981). Influence of prostaglandin $D_{2}$ and prostacyclin on oviduct motility and blood pressure in the domestic hen. Arch. int. Pharmacodyn., 250, 330-332.

(Received September 3, 1985. Revised October 18, 1985. Accepted October 22, 1985.) 